\title{
Structural Challenges of Knowledge-Based Economy in Iran
}

\author{
By \\ Mojtaba Valibeigi ${ }^{\left.1^{*}\right)}$, Ahmad Mohammadi ${ }^{2}$, Mojgan Valibeigi ${ }^{3)}$ \\ ${ }^{1)}$ Visiting Professor of Public Administration, University of Victoria \& Assistant Professor of Buein Zahra Technical \\ University, Buein Zahra, Qazvin, Iran \\ 2) Assistant Professor Of Buein Zahra Technical University, Buein Zahra, Qazvin, Iran \\ 3) Master of Business Managemen; Expert Of Contracts Department Of Mellat Bank \\ ${ }^{*}$ Corresponding Author: mojtaba.valibeigi@gmail.com
}

Submission: April 23, 2020; Accepted: June 13, 2020

\begin{abstract}
The knowledge-based firms can both flourish and grow employment and economic growth. Knowledge-based firms' protection law in Iran faces serious challenges that cause this law will not reach its aim. Based on this, a documentary research method and indepth interviews are used to understand the challenges facing the Iranian knowledgebased firms. The first challenge is about the definition of these kinds of firms that weren't designed in accordance with demand and the knowledge economy and the learner's economy has been ignored. The second challenge is related to performance mechanisms in financial support and providing the facilities for these kinds of firms, which reveals the weakness of mechanisms against the economic surplus and corruption. These challenges caused gaps including the weakness of needed mechanisms for the illegal subsidy banning, dependent situation of the innovation and prosperity fund, Khosoulati pressures, enterprise approach of the government, governmental inter-authority competition and the weakness of participant attraction of the public and private organizations that hinder the movement towards a knowledge-based economy.
\end{abstract}

Keywords: Knowledge-Based Economy, Knowledge-Based Firms, Knowledge-Based Firms' Protection Law, Polices Of Reducing Unemployment, Iran.

\begin{abstract}
ABSTRAK
Perusahaan berbasis pengetahuan dapat berkembang dan menumbuhkan lapangan kerja dan pertumbuhan ekonomi. Hukum perlindungan firma berbasis pengetahuan di Iran menghadapi tantangan serius yang menyebabkan hukum ini tidak mencapai tujuannya. Berdasarkan hal tersebut, metode penelitian dokumenter dan wawancara mendalam digunakan untuk memahami tantangan yang dihadapi perusahaan berbasis pengetahuan Iran. Tantangan pertama adalah tentang definisi jenis perusahaan yang tidak dirancang sesuai dengan permintaan dan ekonomi pengetahuan dan ekonomi pelajar telah diabaikan. Tantangan kedua terkait dengan mekanisme kinerja dalam mendukung keuangan dan menyediakan fasilitas bagi perusahaan semacam ini, yang mengungkapkan kelemahan mekanisme terhadap surplus ekonomi dan korupsi. Tantangan-tantangan ini menimbulkan kesenjangan antara lain lemahnya mekanisme yang diperlukan untuk pelarangan subsidi ilegal, situasi ketergantungan dana inovasi dan kemakmuran, tekanan Khosoulati, pendekatan perusahaan dari pemerintah, persaingan
\end{abstract}


antar otoritas pemerintah dan lemahnya daya tarik peserta dari publik dan swasta. organisasi yang menghalangi pergerakan menuju ekonomi berbasis pengetahuan.

\author{
Kata Kunci: Ekonomi Berbasis Pengetahuan, Perusahaan Berbasis Pengetahuan, Hukum \\ Perlindungan Perusahaan Berbasis Pengetahuan, Kebijakan Pengurangan \\ Pengangguran, Iran.
}

\title{
INTRODUCTION
}

In spite of the codification and performing of the small and medium firms' support, upon to command No. 12868 from the Resilient Economy Headquarters via the Industry Ministry through the facility paying equal to 5 billion US dollar( 16 thousand billion Tomans $\left.{ }^{1}\right)$, this plan failed to perform. Central Bank official statistics show the mining and industry group negative improvement during the past 6 month of 1396

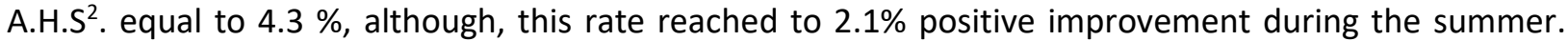
Growth rate decreased and reached to $-0.9 \%$ (CBI, 2017). Stagnation, thus, is the first issue of the small and medium industry firms.

Ministry of Industry, Mine and Trade, also, stated that 26 million dollar facilities have been payed which $84.6 \%$ of it consumed in working capital providing and only $9.9 \%$ used for generating and developing of the mining and industrial firms (Ministry of Industry Mine and Trade, 2017). Early another national job making plan which performed in 1384 A.H.S base on $4^{\text {th }}$ law plan of economic development was Small Businesses and Entrepreneurs Quick Economic Plan (SBEQEP). This loans were given to the firms to buy raw material and equipment, reaching the aims such as producing and non-oil exportations increasing, economic mobility enhancement, job making improvement and making the new job situations.

Obtained results of the plan performing were assessed by Majles Research Center and The General Inspection Organization of Iran (GIO) and they stated, the results are frustrating and the plan failed in performance. The GIO report has been presented in Esfand of 1387 A.H.S. upon to 4665 samples in 23 provinces (The General Inspection Organization of Iran, 2009). Facility payment in some cases has been opposite to the determined aims in $4^{\text {th }}$ law plan and could not provide the environment of industry growth and subsequently the exportation and employment booming. About $17.44 \%$ of plans were fake and the facility applicants consumed the facilities in another projects. About the $40 \%$ of pledged employment in plan has been achieved and remained $60 \%$ have had deviation from the original plan. Upon to harmonic arithmetic mean and harmonic geometric mean there are 21.95 and 16.92 percent deviation of the original plan respectively. It means that some of the facility recipients consumed the resources in another place partially or completely. Eventually, the Majles Research Center announced that the facility giving to the small and medium economic firms has been faced to failure (Islamic Parliament Research Center, 2008).

One billion dollars' budget has been assigned to Presidential Innovation and Prosperity Fund Which is supposed to use for the knowledge-based firms. In 1394 A.H.S also, the Innovation and Prosperity Fundapproved about 75 million dollar facilities. This fund was approved along with the implementation of law No. 123 of Constitution of the Islamic Republic of Iran, in 1389 A.H.S. to support the knowledge-based firms and institutes and commercialization of the innovations and inventions in the Islamic Consultative Assembly. Article 5 of this law states that a fund should be established as Innovation and Prosperity Fund dependent on the High Council of Science, Research and Technology. Innovation and

\footnotetext{
1 - Iranian Rial or Toman is the official currency of Iran. At that time, Toman exchange rate to the dollar was $1 \$$ equals to 3280 Toman.

2 - Anno Hegirae Solaris
} 
Prosperity Fund was established in 1391 A.H.S to commercialize the innovations and inventions, making the knowledge applicable and complete the chain of Idea/Product/Market. Generally, the final aim of this fund is to help the economic improvement in the country via the knowledge-based and top technologies domain.

Based on various researches, the knowledge-based firms in Iran don't have satisfying qualitative and quantitative conditions, even upon Iran's 20-year vision plan (1404 A.H.S). the most important challenges against of these kinds of firms include unbalance governmental protection policies, the conceptual challenge in treatment to knowledge-based firms, industry, internal market stagnation and economic problems, whereas the most significant factors in succession are financial supports and factors (Akbarzadeh \& Shafiezadeh, 2013; Chaharband \& Momeni, 2011; Fakhari, 2015; Gholipour, Vahdatzad, Owlia, \& Khademi, 2016). Mostly, this law faces two main challenges, the first one is the conceptual challenge about the definition of these kinds of firms and the second one is about the implementation mechanisms. Therefore, this study has investigated structural challenges knowledge-based economy in Iran which caused failure the Iranian Knowledge-based firms' protection law.

\section{METHODS}

The research uses a documentary research methodology as well as some in-depth interviews for identifying most challenges facing knowledge-based firms. Accordingly, with reference to the relevant documents and statistics like The Central Bank Statistics of Iran, Islamic Parliament Research Center(IPRC), General Policies of Fifth Development Plan, Ministry of Industry, Mine and Trade of Iran, (MIMT), The General Inspection Organization of Iran (GIO) and the Islamic Republic of Iran Customs Administration (IRICA) and some in-depth interviews with some heads of knowledge-based firms have been tried to determine how polices, sources and goals in the field have not been achieved. Accordingly, the paper consists of 3 main sections. In result section will be studied: the knowledge-based economy; the conceptual challenges against the knowledge-based firms' support in Iran and functional challenges. In discussion section, a pathology of protection law implementation mechanisms of knowledge-based firms in Iran will be investigated and finally the topics, will be summarized and concluded.

\section{RESULTS}

\section{Knowledge-based Economy}

Knowledge-based firms are found in various scientific papers via different definitions such as KnowledgeIntensive Organizations or Business, Knowledge-Intensive SMEs, Technology-based Firms and Innovative Small Firms. Based on jones (1989), it can be said that the first study in this domain has done by Lytle in 1979. He introduced this firms as institutes, rely on innovation and scientific inventions and are established for the innovations and inventions' commercialization (Jones, 1989). Literature review in this domain shows that various researchers have concentrated on different properties, defining the knowledge-based firms; this diversity, thus, make it difficult to have a specified definition of this firms. The related studies can be classified in 3 parts: researchers who concentrate on these firms' inputs, for the knowledge-based firms' definition. Second group are researchers who focus on these firms' outputs and third group have considered the overall value cycle in these firms. As an instance of first group, Starbuck, comparing the knowledge-based term with popular economic terms such as stock-based or power-based, stated that in knowledge-based firms, the knowledge is the most important input (Starbuck, 1992). Strong base knowledge has been taken in account by Alvesson (2004) as the key characteristic of these firms. other researchers, also, defined the knowledge-based firms, concentrating on terms such as knowledge basement, knowledge powers or the knowledge-based experts as the main input parameters (Ditillo, 2004). In second group, a wide range of researchers have defined the knowledge-based firms based on their outputs (Rylander \& Peppard, 2005; Zack, 2003a, 2003b). For 
example, the knowledge-based firms have been introduced as businesses that sell their knowledge (Sveiby, 1997). The knowledge-based products and services also have this approach. Most of organizations, based on this approach, have presented a diverse definition about the knowledge-based services and products. Using of the product type as an index for the recognition knowledge-based firms, has become more common due to its simplicity. On the other hand, the products or services are the only reflection of observable part in an organization, whereas the greatest part of it are concealed and it should be said that the knowledge-based firm characteristic are more than kind of products and shows itself by processes, targets and its future outlook (Zack, 2003a, 2003b). It is even possible that the production process not be knowledge-based and consists only of main component import and their assemblage, despite of its advanced appearance. Therefore, using of the products or services as a device for classification or definition of knowledge-based firms, is not enough and convincing (Hatzichronoglou, 1997). Currently, same approach in Iran is followed by vice-presidency for science and technology for the recognition and protection of knowledge-based firms. A more complete approach has been originated then, considering the existed shortcoming. In this approach, overall value chain of a market is considered for the knowledge-based firms' definition. European Union for example considers some indices in small to medium scale knowledge-based firms, including innovation input index, innovation functionality index and innovation output index (Etzkowitz \& Leydesdorff, 1995; Wiklund \& Shepherd, 2003). The knowledgebased firms, indeed, use the knowledge as a factor for the value-add increasing than their competitors, via a perfect knowledge management. Some researchers such as Lall (1992), Bell and Pavitt (1992), Ariffin and Figueiredo (2004) have done valuable studies about the process-based approach in analysis of technological capability.

\section{Conceptual challenge of knowledge-based firms in Iran}

In Iran, upon to article 1 of the knowledge-based firms' protection law that approved in 1389 A.H.S, the knowledge-based firm is define as a private or cooperative institute or firm which consisted for the knowledge and wealth Synergistic, the economic-oriented knowledge developing, catching the scientific and economic targets, commercializing the research results and developing the high-tech domain with abundant value added. The validation index of knowledge-based firms in Iran is also formed based on output-oriented approach, as it defined previously. The knowledge-based products have been explained in that regulation including: 1. It located in high or the average high technology domain. 2. It has technical complexity and its production and continuity depends on research and development. 3 . Its main added value initiates from the technical knowledge and innovation.

The knowledge-based economy term, which has been emphasized by the Organization for the Economic Co-operation and Development (OECD), reveals the knowledge and technology significant role in economic development path. Upon to that, the knowledge-based economy is a kind of economy which formed base on production, distribution and application of the knowledge and information and the investment on knowledge and fundamental sciences being especially considered (Hatzichronoglou, 1997). In other word, the knowledge-based economy, such an economy which the knowledge production, distribution and consumption is the main resource of the stable growth and making wealth in society (Foray \& Lundvall, 1998). The World Bank survey shows that the developing countries have not been successful in knowledge-based economy implementation, however, the final goal of knowledge-based economy have been the stable development, especially in poor and developing countries; some experts, therefore, believe that the learning economy initially can be the foundation of the knowledge-based economy for developing countries (Foray \& Lundvall, 1998). The organizations and countries success, in learning economy, is the reflection of their ability in learning. The important point in this issue is that the learning economy is not a high-tech economy necessarily, but it is an economy that learning is happened in all part of it. The difference between the learning and knowledge-based economies is their different focusing on leaning and knowledge respectively. Moreover, the developing process, in developing 
countries, is a learning process rather than innovation (Viotti, 2002). So, the learning approach, intelligent technology transfer, inverse engineering, localization and the knowledge management in all economy layers, are the better strategies than the focusing on advanced technologies, in Iran. Upon to some researchers' view, the best procedure of research and development in developing countries, is the learning and localization of the imported technologies. Eventually, it seems that the prevailing technological strategies of country atmosphere, should be based on learning economy theories as the knowledge-based economy prerequisite. Currently, the most popular strategy for the innovation development is the focusing on research and development activities, especially the advanced technologies, while the industrial structure in developing countries, mainly, based on the average and low technologies. The share of these firms in production and economy growth is more than the firms which based on high technologies. In other word, the employment and economy growth burden is depended on the sectors, based on average and low technologies but the governmental and political protections are little about them.

On the other hand, the policymakers and government officials disregarding to those firms have caused the gaps of these industries. Therefore, it is necessary to survey precisely about the focusing on advanced technologies, in a developing country. The first point is that some studies revealed that there is no obvious relationship between the high technology and the rate of national production (HirschKreinsen, Jacobson, \& Robertson, 2006). Financial and humanitarian constraints in Iran and heavy investment need in research and developing, On the other hand, will seems inappropriate for Iran in advanced technology strategies. The other important point is that the firms, established on average and low technologies are effective in the advanced technologies' success. Because the advanced industries don't work in isolation. The different level relationship of technology will cause the knowledge distribution among the various parts of the industry. The circumstance of the advanced technology market is that the costumers and users of these technology should have the ability of conformity to technology. Disregarding the ability development based on low and average firms, with technology gap, make the high technologies small indirectly. It should be considered that the science and technology in different fields and levels, is an interconnected system, as it is not possible to improve without the hierarchy and chain structure passing of the system. In other word, the newest technologies' commercializing need some technical backgrounds and infrastructures which have been made in previous technologies and some countries such as Iran doesn't have them. For example, the electronic device generation as a modern technology is one of the biggest consume markets of Nano powders, while Iran is far behind the industrial countries and has a limited market. Therefore, Iran will have the plenty of problems and limitations in commercialization and making a market for the Nano powders in electronic industry. The production and export changes in successful developing countries show that they began their work, using the low level technologies and then located progressively in low layers of the advanced technologies in universal production chain. So it seems altogether, that focusing on the advanced technologies in developing countries will cause the technology gap, upgrading lack of the lower level technologies, unconformity with high technologies and finally making the high level industry smaller and the lack of the economic justification, consequently. Moreover, the just focusing on this strategy in developing countries, basically, is not a proper and logical strategy for the stable development.

The knowledge-based firms, beyond their productions, are knowledge-based in different level of their activities (Håkanson, 2010; Rahmeyer, 2007). As the core of the knowledge-based activities, innovation, is a pervasive phenomenon and can emerge in all sectors of the industry, regardless of the type and level of technology. Generally, all kind of the firms with various levels, are faced to distinct solution selection issue in their activities for the production or services. But there are few solutions which make the most added value than the other rivals and just recognized by knowledge. The key role of related knowledge is that know to how combine the resources such as raw materials, manpower, energy and the other resources to make more value than the other rivals for customers. So, using this knowledge and 
management in divers' layers of an organization activities, make it a knowledge-based firm. The knowledge-based firms, indeed, utilize the knowledge in different layers of their activities and make their productions distinct. With such a view, a knowledge-based firm doesn't mean the generation of high technology products, but it means the innovative and valuable products with any kind of technology level. Even, some researchers believe that the average and low level industries with lower cost on research and development can be knowledge-based (Lundvall \& Lindgaard Christensen, 2004). The main target of the focusing on knowledge-based economy in Iran is the achievement to the stable development. One of the main principles in stable development, thus, is the national production increasing and responding the major countries' demands. Table 2 shows major import items of the country in 2012 (the Islamic Republic of Iran Customs Administration, 2012). Iran, upon to table 1, extremely depends in its primary needs and requires the active presence of entrepreneurs, especially innovative firms in these sectors. In this table the advanced industries' products based on OECD definition, have been indexed as starred form.

Table 1. Classification of The Importation Items to Country In 2012, Based On Subject Separation

\begin{tabular}{|c|c|c|c|}
\hline Import item & percentage & Import item & percentage \\
\hline Food products & $26.43 \%$ & $\begin{array}{l}\text { Crystal, decorative and artistic } \\
\text { products }\end{array}$ & $5.14 \%$ \\
\hline Mechanical devices and machinery & $16.27 \%$ & Transportation devices & $4.93 \%$ \\
\hline Metal and related products & $13.73 \%$ & Medications* & $2.75 \%$ \\
\hline Mineral and chemical products & 9.32 & Optical and precise devices & $2.14 \%$ \\
\hline $\begin{array}{l}\text { Plastic materials cellulose and } \\
\text { textile }\end{array}$ & 7.85 & Aerospace vehicles & $0.34 \%$ \\
\hline Visual-audio and electrical devices & $6.8 \%$ & etc. & $4.3 \%$ \\
\hline
\end{tabular}

Source: The Islamic Republic of Iran Customs Administration, IRICA. (2012)

The table shows that, the high level industries, have much less weight than the average and low level kinds in responding to country's main requirements ( $12.03 \%$ of total importation). Hence, via the viewpoint change and considering the country's demand instead of the focusing on high level technologies, it will be possible to respond the basic requirements of the country. It means that the most of products and services can be localized in Iran via the using of knowledge and innovation benefits in knowledge-based firms. However, these needs might be localized based on high level technologies or the ordinary or older technologies. The important point is the stable development and the country's needs responding by the abilities of the internal knowledge-based firms. Figure 1 shows the country industry priorities based on expert studies of the ministry of industry in 1391 (A.H.S) (Ministry of Industry, 2013). 


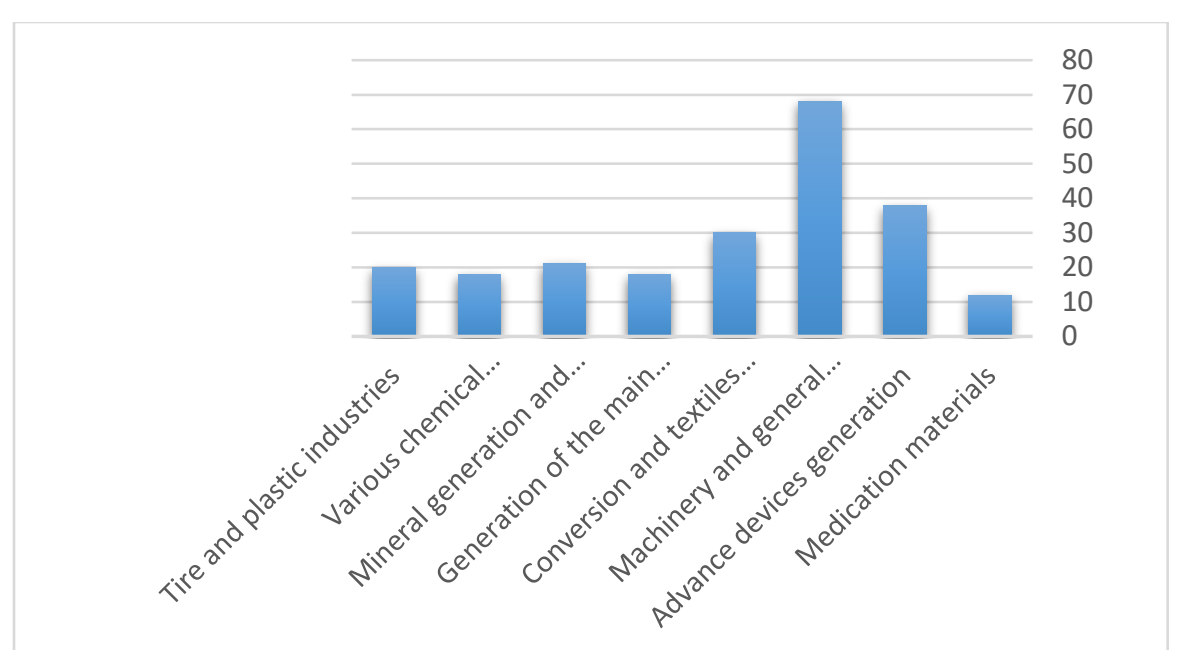

Figure 1. The Country Priorities Upon to Industry Ministry in 1391 A.H.S (2013)

Upon to that graph only $22 \%$ of country essential industrial needs belongs to high level technologies, while the $78 \%$ belongs to low and average level technologies. Moreover, Iran, in lots of basic industries, needs generally to the products, related to many years ago. UNESCO has published a report in $\mathbf{2 0 1 0}$ about the knowledge-based economy growth and the relationship between the science and technology. It says: Development and research in Iran has not succeeded in finding the target and determining the market needs and has focused on some high level technologies instead of that (Brito, 2010). The science and research in Iran, has been far away from the social- economic needs, relying on the oil revenues; this caused the little share of the science and technology in Iran's industrial development and the high rate of raw material exportation. The knowledge-based products, nowadays, have a main role in countries' economic development and is still rising. The main feature of these products which recognized as the new revolution of the industrial development, is the high quota of the research and development in products and services.

The profitability of the technological products does not just depend on the difference of the cost and price but there are lots of factors such as internal and environmental issues are effective in a product's profitability. As an example, the evaluation of the benefit of most investors in Information Technology (IT) as an important branch of the knowledge-based products has not shown proper results (Kohli \& Devaraj, 2003). Most of the technological product firms, in 1990 decade, spent a lot of money in their products ads but they did not obtain the investment returning as it expected. In Iran, on the other hand, the small industrial firms with the low and average technology level have obtained more benefit and the medium firms, also, have gotten the maximum profit via the low level technology (Fakhari, 2015). One of the most reasons in those kind of profits' ambiguity is that the investment in knowledge-based industries has a long-term essence and therefore the general financial mechanisms for the assessment and financial supply are not suitable for them. Due to existed risks, the banks usually are not interested in investment in knowledge-based activities. The most suitable investment device in knowledge-based plans, thus, is the venture capital. The high added value in knowledge-based industries, from the investing perspective with solely economic considerations, usually are assessed in a packet of investments (portfolio). Risky investors optimize their portfolio, considering the failure of the economic return risk in some plans. Therefore, some plans inaccessibility to their economic targets, is not the criterion of total failure. So, it is not logical to expect the high profit of each investment and consequently the high rate of the efficiency for the investment plans' acceptation. Furthermore, the added value issue completely performs, opposite to its general definition, due to their risky, potential and unknown market of 
knowledge-based plans. In other word, these technologies with high risk don't have little economic justification, due to the technology novelty and plenty of problems and lack of the market expansion.

The market of potential knowledge-based plans usually is unknown and risky. The statistics show that the average of failure rate for the technological products in market is the $50 \%$ upper of other productions (Fakhari, 2015). Moreover, the innovative activities naturally are risky and along with the uncertain costs and their capital returns are potential (Fakhari, Salmani, \& Daraei, 2013); because the obtaining of the appropriate result in product market is long and time wasting. Considering the abovementioned content, the expectation about the market conquering and fast responding in knowledge-based products is not logical. Other important point is that the business inappropriate environment increases the risk of knowledge-based product in market. Generally, the environmental tensions affect the firms' living extremely while the knowledge-based firms have the more complicated and difficult situations due to their complex parameters. The knowledge-based firms in Iran are faced to various and complex challenges for the problems dominance, market penetration, obtaining the proper benefits and the life continuing. Iran's economy is mainly governmental or quasi-governmental which usually has an inflexible and heavy bureaucratic body; whereas the knowledge-based firms have the agile and flexible body due to their innovative nature. Therefore, in knowledge-based firms' definition based on the country circumstances, the private section benefits should be utilized in knowledge-based technology development. The private section keyword as an intelligent allocation in Iranian knowledgebased firms' definition revealed that. Since the commercializing in Iran, is the lost factor in the research and production chain, the utilizing of the knowledge-based firms' potential in filling this gap can be a significant step in technology development via the innovations commercialization and making the researches applicable. In first step, the conceptual challenge against these firms should be eliminated for the effective financial protection. Fakhari (2015) definition of the knowledge-based firms, thus, could be taken in account as the criterion. Upon to that, the knowledge-based firms in Iran, mainly are some organizations (mostly small and medium) in private sector (Structural class) which generated and managed by experts (resource class) to commercialize the innovations and inventions, making the researches applicable (process class) and localizing the technologies (production class). In these firms, the research and development is the main core of the activities (process class). The competitive advantage of these firms, is the technical knowledge and scientific abilities from the knowledge and innovation in various levels (market class). These firms have grown in a changing and knowledge-based environment (Growth model class) and have the long-term profitability (market class). Broadening the definition domain of the knowledge-based firms based on the current situations of Iran, makes the financial supports of these firms more logical and with lower risk in addition to vast responding to their demands.

\section{Financing Problems of knowledge-based firms in Iran}

Big firms, especially the stock companies have the lesser problem for the financing, because they can sell their stocks easily to provide their needed capital and also they have more easy access to the bank credits. But the knowledge-based firms face to limitations in financing, especially in the stage of entering the market. The small businesses could not be successful without the enough financing. Finding the enough needed financial supports and the business development, has always been a big challenge against the knowledge-based firms and without the financial providing, the new businesses will not be successful. Most of the entrepreneurs have given up the new businesses and don't commercialize their financial ideas due to limitations of access to financial resources. In every country, governments and public organizations try to provide the small business opportunities via the infrastructures making to generate the growth areas and economic developments for their countries. One of those infrastructures are the financial aids and giving the facilities and needed investments for the business activities' beginning. During the recent years, some organizations and governmental authorities in Iran have tried to help these firms. About the 50 organization, authority and plans in Iran participate in financial services and facilities 
which most of them are in idea to commercial steps. As it can be seen in figure 2, the knowledge-based firms, suffer from financing in growth step to the market. The banks are not interested in investment in these firms in this stage (growth stage) due to lack of suitable authorities in this step in one hand, and on the other hand, the Iran's financial system doesn't have those mechanisms to protect the knowledgebased firms.

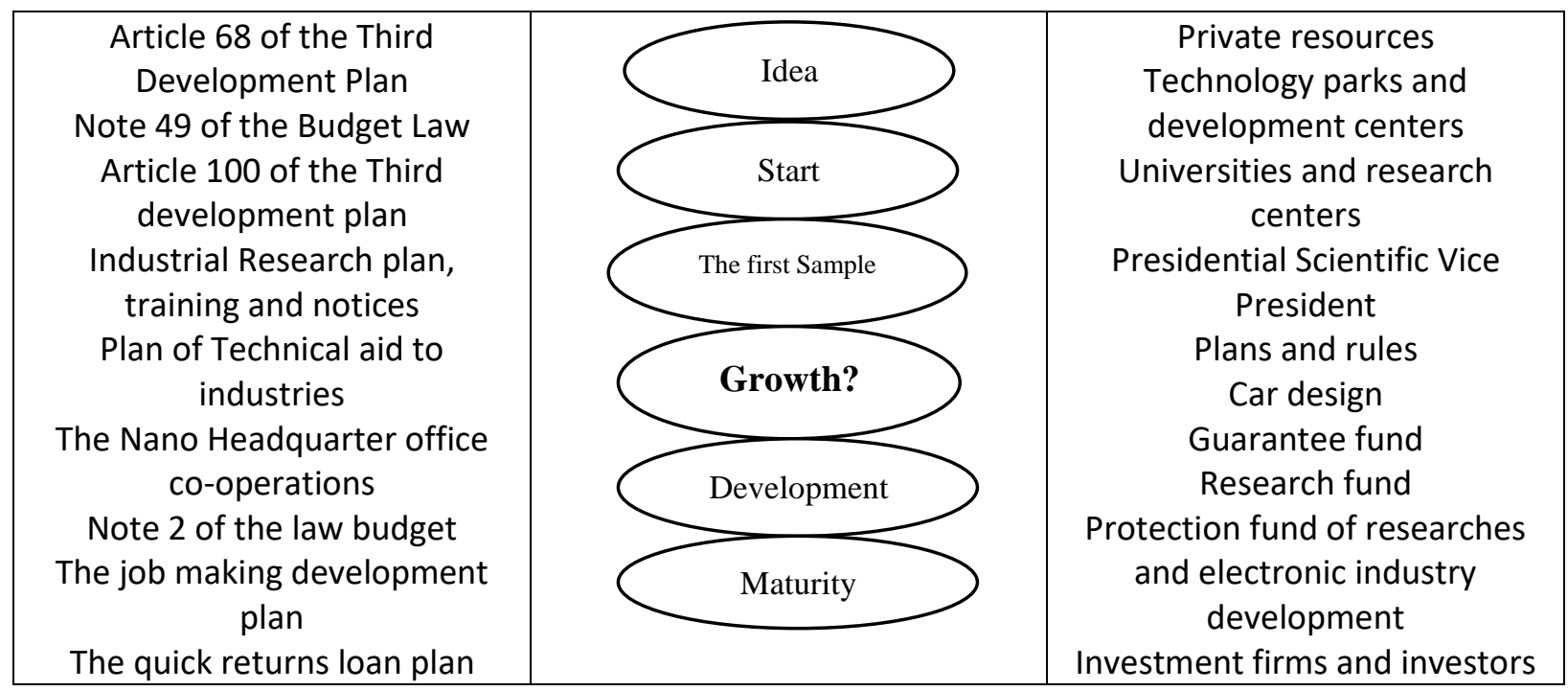

Figure 2. Stages of Knowledge-Based Firm Growth and Government Support in Iran

Each step of small and medium knowledge-based firms' life (Table 2), has especial property, considering their risk level and efficiency. So, the financing is unique for each step, so the potential role of these firms, usually will not be achieved in Iran. Because the needed properties of these firms such as financing infrastructures and venture capital don't exist enough. Functionally, these firms could not follow the essential processes such as research and development, innovation and commercializing as a stable form. Hence, the financial part of economy in Iran, has not served the real part of it to make an information symmetry and resource guiding for the efficiency increasing in small and medium knowledgebased businesses.

Table 1: Each step of small and medium knowledge-based firms' life

\begin{tabular}{ll}
\hline \multicolumn{1}{c}{ Step Name } & \multicolumn{1}{c}{ Description } \\
\hline Conceptual & $\begin{array}{l}\text { It begins with an invention or innovation. The job making team has not been generated, } \\
\text { step }\end{array}$ \\
the schedule and research plan has not been made. The investment firms are not \\
interested in investment in this step. Risk is high and profitability is low \\
step & $\begin{array}{l}\text { Business operation, the management team determination, the market and costumer } \\
\text { analysis, financial supply from the more official resources, risky investors are interested } \\
\text { in investment }\end{array}$ \\
First step & $\begin{array}{l}\text { Now the firm has succeeded in business, the potential of products' presentation, has } \\
\text { been approved and the firm has income. The risky investors are interested in } \\
\text { investment. In this step, it needs more financial supply for the protection of product } \\
\text { and attempt contents. } \\
\text { Second step } \\
\text { Selling the products and services, has an important role in assets' increasing. In this } \\
\text { step the firm reached to equal point and the financial currents' management is needed. } \\
\text { In this step the risky investors are more professional. }\end{array}$
\end{tabular}


Third step

All systems work well, the profit is modified and Balance sheet is consolidated. The firm has achieved a considerable share of market and penetrated in market deeply.

Fourth step The firm is faced to public presentation, catching, selling and combination. The idea now has become to reality.

Most of interpreters, consider a financing gap for these firms. This means that, if the financial resources be available, the huge number of firms can use from the financial resources, in an efficient and effective form; but these firms could not provide it from the official financial system. Studied, have done by Central Bank of the Islamic Republic of Iran (CBI) shows that financing makes about $36 \%$ of these firms' problems. Commercial banks, usually prefer to deal with big industries which their products guaranteed and small producers, are not supported by commercial banks, due to their unguaranteed future and high probability of bankruptcy. The amount of paid loan is also very low and these small industrial units can find some sponsors after the attracting customers' trust and improving their stability. In this way, the lots of production units give up and be eliminated from the business cycle. Therefore, a financing mechanism should be generated in Iran's financial system.

\section{Discussion: Pathology of protection law implementation mechanisms of knowledge-based firms}

Needed mechanisms' weakness to deal with collusion and illegal subsidy in knowledge-based firms is the main barrier in their implementation, considering the previous governmental support plans. There are lots of factors, participate in this problem, for example the Innovation and Prosperity Fund dependence to the government or the pressure of semi-governmental organizations (Khosoulati) to that. Governors can put the fund under pressure due to their membership in board of trustees or board of directors via illegal suggestions or intermediations. Nongovernmental public organizations growing which depend to the government or belong to it, on the other hand, is one of the most important realities during the recent years. This organizations, nowadays, called Khosoulati organizations, in unofficial literature. They can put the other involved organizations in knowledge-based firms' support, under the pressure. This process continuing will cause the fund trouble in the future. Therefore, the innovation and prosperity fund should be independence. Enterprise Ownership approach instead of the sovereignty approach is another subject that deviated the implementation mechanism from its true path. Governments play various roles in financial and nonfinancial supports of knowledge-based firms. In some cases, the government, invests in knowledge-based firms directly via the investment fund founding or facility granting to the knowledgebased firms. But the main role of the government is indirect.

The main duty of the government is to modify the business space and make a suitable platform for innovation, so that economic and legal infrastructures or help to make a network of investors. The reality is that huge knowledge-based firms have grown via the diverse tools of the nongovernmental financial supply instead of governmental facilities and loans. The most important role of the governments is that to make an appropriate space for the private financial organizations such as Venture Capital (VC) funds or proper law codification for crowed funding activities. However, the function of this rule is understood equal to innovation and prosperity fund operation. Incentive policies about the innovation development in various countries, has moved from the direct approach to indirect one. In this condition, the government enhances the market mechanisms instead of its direct facing to the small and diverse knowledge-based firms. In this situation, the function of innovation and prosperity fund is changed instead of that it does its duties such as recognition, selection and project supervision and giving the facilities. In indirect approach this fund changes to a fund for development of the nongovernmental risky funds or encouraging the other organizations such as banks and investment-insurance organizations for the investment. In other word, the right situation of the innovation and prosperity fund is the mother of the other funds. Knowledge-based law and its implementation has moved to a direction that the innovation and prosperity fund enters to the challenges, directly. Government direct entrance always 
caused the unnecessary increasing in governmental bureaucracy. Governmental depravity increases the financial services in different parts. For example, the governmental fund managers, rarely welcome to government assistance to the knowledge-based firms or risky investment in this kind of firms; An intervention in market which prevents the generation and development of market mechanisms in nongovernmental section. For instance, the private venture capital fund could not improve easily due to the Innovation and Prosperity Fund (IPF) growing; because the idea owners prefer to use the fund facilities instead of the giving their stocks to such funds. This, causes the deprivation of business management services, the lack of private fund growth and decreasing of the knowledge-based firms' efficiency. Conflicts and disputes between various government agencies for the financial resources' attraction in one hand, and the main government responsibility ignoring in regulatory authorities setting up on the other hand, have a significant role in technology development.

Competition among the different governmental organizations for the confiscation of law and executive activities, is one of the most important subjects as an undeniable form during the recent years. The intensity of this competition was to the extent that at the beginning of Government of Hassan Rouhani (2013), a five-person committee was held among the Vice-President of Science and Technology (ISTI), Ministry of Science, Research and Technology (MSRT) and a person who was acceptable by the two other participants, and the main subject of this committee was about the related subjects to the knowledge-based firms. This conflict was not resolved after the committee, so the Supreme Leader of Iran called the science minister and vice-president to solve the argument. The competition among the authorities is a failure, exists in the field of science, technology and innovation yet.

The role and situation of the Vice-president of Science and Technology in law implementation is one of the most important ambiguities in this subject, because there is no role for this authority in one hand, but, this authority knows itself as the main custodian of knowledge-based firms' protection and helping them to commercialize their achievements, on the other hand. If this kind of conflicts in law implementation not controlled at primary steps, there will not be a great hope to efficiency and functionality of the support contained in this law. Some inconsistencies are observable in this issue, such as the related topic to workgroup of knowledge-based recognition transfer from the Vice-president of science to the Supreme Council for Science, Research and Technology (SCSRT). Due to the most science and technology experts' idea, the custodians of the education and technology should be separated.

\section{CONCLUSION}

Investigating the knowledge-based firms' protection law, reveals the functional and conceptual gaps. In conceptual domain, the definition way of knowledge-based firms makes a procedure to protect those kind of firms, which don't have economic justification and will not cause the joblessness reduction and economic development; a personalize behavior, on the other hand, to accept or refuse the knowledgebased firms, is another failure of the conceptual definition of this plan. In functional mechanism domain, there are failures yet, which the other previous job creation plans in Iran were also, faced to them. These gaps include the weakness of needed mechanisms for the illegal subsidy banning, dependent situation of the innovation and prosperity fund, Khosoulati pressures, enterprise approach of the government, governmental inter-authority competition and the weakness of participant attraction of the public and private organizations.

According to the above, it seems that the most appropriate investment device in knowledgebased plans is the logical-venturous investment. Such the logical-venturous investment should give the financial facilities to the small and medium scale knowledge-based firms at the market entry in the growth stage. First step towards effective supports is the high financial transparency and mandatory in the logicalventurous investment. Most of the present problems of the state and private banks in Iran is due to their non-compliance with international standards and also, the International Financial Reporting Standards (IFRS) doesn't be applied in most of the Iranian banks, caused the lack of transparency in Iranian banks, 
consequently. The logical-venturous investment should adhere to the standards from the foundation stage. Transparency will be more in consequence of the new report investment applying. And the government must increase the competitiveness in national economy and the economic firms' efficiency while it reduces its enterprises, based on the main principles of the article 44 general policies (Khamenei, 2009, 2010, 2011, 2012).

\section{REFERENCES}

Akbarzadeh, Najmeh, \& Shafiezadeh, Ehsan. (2013). A Study On The Role of Government in Improving The Process of Launch and Development of Knowledge-Based Businesses. Roshd-E-Fanavari, 9(33), 46-53.

Alvesson, Mats. (2004). Knowledge work and knowledge-intensive firms: OUP Oxford.

Ariffin, Norlela, \& Figueiredo, Paulo N. (2004). Internationalization Of Innovative Capabilities: CounterEvidence From The Electronics Industry In Malaysia And Brazil. Oxford development studies, 32(4), 559-583. https://doi.org/10.1080/1360081042000293344

Bell, Martin, \& Pavitt, Keith. (1992). Accumulating Technological Capability In Developing Countries. The World Bank Economic Review, 6(suppl_1), 257-281.

Brito, L. (2010). UNESCO science report 2010: The Current Status Of Science Around The World. United Nations Educational, Scientific, Cultural Organization.

CBI, The Central Bank of Iran. (2017). Reports Of The Mining And Industry Group Retrieved From https://www.cbi.ir/page/4275.aspx

Chaharband, Farzaneh, \& Momeni, Farshad. (2011). Challenges And Perspectives In Knowledge Based Development In Iran: Basic Education Approach. Journal of Economic Growth and Development Research, 1(4), 75-115.

Ditillo, Angelo. (2004). Dealing With Uncertainty In Knowledge-Intensive Firms: The Role Of Management Control Systems As Knowledge Integration Mechanisms. Accounting, Organizations and Society, 29(3-4), 401-421. https://doi.org/10.1016/j.aos.2003.12.001.

Etzkowitz, Henry, \& Leydesdorff, Loet. (1995). The Triple Helix University Industry Government Relations: A Laboratory For Knowledge Based Economic Development. EASST Review, 14(1), 14-19.

Fakhari, Hossein, Salmani, Davoud, \& Daraei, Mohammadreza. (2013). The Impact of Economic Sanctions on The Knowledge-Based Companies in Iran. Journal of Science and Technology Policy, 5(3), 1-16.

Fakhari, Hussein. (2015). Review of Knowledge-Based Firms Definition Consistent with The Economic Conditions of Iran. Journal of Science and Technology Policy, 6(4), 69-88.

Foray, Dominique, \& Lundvall, B. (1998). The knowledge-based economy: from the economics of knowledge to the learning economy. The economic impact of knowledge, 115-121.

Gholipour, Mojtaba, Vahdatzad, Mohammadali, Owlia, Mohammad Saleh, \& Khademi, Zare Hassan. (2016). Identification and Priorities Kbes Challenges Using Ann Method (Case Study: Yazds Kbes). Roshd-E-Fanavari, 12(45), 17-25.

Håkanson, Lars. (2010). The Firm As An Epistemic Community: The Knowledge-Based View Revisited. Industrial And Corporate Change, 19(6), 1801-1828. https://doi.org/10.1093/icc/dtq052

Hatzichronoglou, Thomas. (1997). Revision of the High-Technology Sector and Product Classification, OECD, No. 1997/02, OECD Publishing, Paris, https://doi.org/10.1787/050148678127.

Hirsch-Kreinsen, Hartmut, Jacobson, David, \& Robertson, Paul L. (2006). 'Low-tech'Industries: Innovativeness and Development Perspectives-A Summary of a European Research Project. Prometheus, 24(1), 3-21. https://doi.org/10.1080/08109020600563762.

Islamic Parliament Research Center, IPRC. (2008). Evaluation of the Research Center of the Parliament from the performance of Small Businesses and Entrepreneurs Quick Economic Plan. Retrieved from http://rc.majlis.ir/fa/news/show/765145 
Jones, Alun. (1989). Science Parks and The Growth of High Technology Firms by C.S.P. Monck R.B. Porter, P.R. Quintas, D.J. Storey, P. Wynarczyk. (Croom Helm, London, 1988), pp. 270. ISBN 0-7099-54417 f35. Prometheus, 7(1), 170-171. https://doi:10.1080/08109028908629053.

Khamenei, Ayatollah. (2009). Leader Announces General Policies of Fifth Development Plan. http://farsi.khamenei.ir/news-content?id=5389

Khamenei, Ayatollah. (2010). Leader Meets with Entrepreneurs. Retrieved from http://english.khamenei.ir/news/1343/Leader-Meets-with-Entrepreneurs

Khamenei, Ayatollah. (2011). Leader's Address to People Active in Economic Sector. Retrieved from http://english.khamenei.ir/news/1508/Leader-s-Address-to-People-Active-in-Economic-Sector

Khamenei, Ayatollah. (2012). Leader Meets Government Officials. Retrieved from http://english.khamenei.ir/news/1654/Leader-Meets-Government-Officials

Kohli, Rajiv, \& Devaraj, Sarv. (2003). Measuring information technology payoff: A meta-analysis of structural variables in firm-level empirical research. Information systems research, 14(2), 127 145. https://doi.org/10.1287/isre.14.2.127.16019.

Lall, Sanjaya. (1992). Technological Capabilities And Industrialization. World development, 20(2), 165-186. https://doi.org/10.1016/0305-750X(92)90097-F.

Lundvall, Bengt-Åke, \& Lindgaard Christensen, Jesper. (2004). Introduction: Product Innovation-On Why And How It Matters For Firms And The Economy Product Inovation, Interactive Learning and Economic Performance (pp. 1-18): Emerald Group Publishing Limited. https://doi.org/10.1016/S0737-1071(04)08001-1.

Ministry of Industry, Mine and Trade, MIMT. (2013). Priorities For The Country's Industry. Retrieved from http://www.mimt.gov.ir/general_content

Ministry of Industry Mine and Trade, MIMT. (2017). Reports About The Mining Industry And Trade. Retrieved from http://www.mimt.gov.ir

Rahmeyer, Fritz. (2007). 10 From A Routine-Based To A Knowledge-Based View: Towards An Evolutionary Theory Of The firm. Elgar Companion To Neo-Schumpeterian Economics, 159.

Rylander, Anna, \& Peppard, Joe. (2005). What Really Is A Knowledge-Intensive Firm. Royal Institute of Technology, 1-28.

Starbuck, William H. (1992). Learning By Knowledge-Intensive Firms. Journal of Management Studies, 29(6), 713-740. https://doi.org/10.1111/j.1467-6486.1992.tb00686.x.

Sveiby, Karl Erik. (1997). The new organizational wealth: Managing \& measuring knowledge-based assets: Berrett-Koehler Publishers.

The General Inspection Organization of Iran, GIO. (2009). Evaluation of the Research Center of the Parliament from the performance of Small Businesses and Entrepreneurs Quick Economic Plan. https://bazresi.ir/index.aspx?fkeyid=\&siteid=1\&pageid=611\&g=33

the Islamic Republic of Iran Customs Administration, IRICA. (2012). Major import items of the country. Retrieved from http://www.irica.gov.ir/Portal/Home/Default.aspx?CategorylD=fd61187e-a0804800-bb4b-0a3d0946cc10

Viotti, Eduardo B. (2002). National Learning Systems: A New Approach On Technological Change In Late Industrializing Economies And Evidences From The Cases Of Brazil And South Korea. Technological Forecasting and Social Change, 69(7), 653-680. https://doi.org/10.1016/S0040-1625(01)00167-6.

Wiklund, Johan, \& Shepherd, Dean. (2003). Knowledge-Based Resources, Entrepreneurial Orientation, And The Performance Of Small And Medium-Sized Businesses. Strategic management journal, 24(13), 1307-1314. https://doi.org/10.1002/smj.360.

Zack, Michael H. (2003a). Rethinking The Knowledge-Based Organization. MIT Sloan Management Review, 44(4), 67.

Zack, Michael H. (2003b). What is a knowledge-based organization. Paper presented at the Proceedings 5th International Conference on Organizational Learning and Knowledge. Lancaster. Reino Unido. 